\title{
STUDY ON VIRULENCE FACTORS OF ESCHERICHIA COLI ISOLATED FROM CALVES SUFFER FROM DIARRHEA
}

\author{
GHADA MAHER ABDEL-HAKEEM MOHAMED ${ }^{1}$; MOHAMED WAEL ABD AL-AZEEM ${ }^{2}$; \\ SERAGELDEEN SULTAN ${ }^{2}$ and AHMED MUSTAFA SAID ${ }^{1}$ \\ ${ }^{1}$ Animal Health Research Institute, Assiut Branch, Egypt. \\ ${ }^{2}$ Department of Microbiology, Faculty of Veterinary Medicine, South Valley \\ University, Qena 83523, Egypt.
}

Received: 28 June 2017; $\quad$ Accepted: 30 July 2017

\begin{abstract}
Diarrhea is an important problem in young calves, especially in suckling beef calves. The mostcommon cause of diarrhea in calves is E.coli. The present study was undertaken to screen for presence of virulence factors associated with colibacillosis isolated from one hundred and twenty five fecal samples of calves suffer from diarrhea (<3monthes). All samples were submitted for bacteriological examination, serotyping and virulence tests (Congo red test, serum resistant test, sereny test and haemolytic activity). Finally molecular Identification by using Polymerase chain reaction (PCR) to detect shiga toxin (stx1, stx2) genes. E.coli isolates were fifty eight isolates (46.4\%). The fecal samples were obtained a Twelve different serotype of E.coli $(\mathrm{O} 26: \mathrm{H} 11, \mathrm{O} 91: \mathrm{H} 21$, O103:H2, O111:H2, O15:H21, O146:H21, O8,O113:H4, O128:H2, O124, O121:H7 and O55:H7). It was recorded forty two isolates $(72.4 \%)$ were congo red positive, forty two isolates $(72.4 \%)$ were serum resistant, eleven isolates (18.96\%) made keratoconjunctivitis of Guinea pig and fourteen isolates (24.13\%) had hemolytic activity. PCR was performed to detect stx 1 and stx 2 genes on different serotypes of E.coli isolates. The serotypes which positive to stx1 gene only were three $(\mathrm{O} 8, \mathrm{O} 113: \mathrm{H} 4, \mathrm{O} 128: \mathrm{H} 2)(30 \%)$, two serotypes were positive to stx2 only (O15:H21,O146:H21) (20\%), four serotypes were positive to both stx1 and stx2 (O26:H11, O91:H21, O103:H2,O111:H2) (40\%) and O124 was negative for both stx1 and stx2(10\%). This result of E.coli strains isolated from diarrheic calves implies that these animals are an important reservoir of Shiga toxin Escherichia coli (STEC) strains that are potentially pathogenic toward farm animals.
\end{abstract}

Key words: Virulence, Escherichia Coli, calves, Diarrhea

\section{INTRODUCTION}

E.coli found is a normal habitant of the gastrointestinal tract and also found in the environment. However, the infection was happened due to break of the protection barrier, highly pathogenic bacteria type or immunosuppression. Clinical disease due to E.coli in calves may be foundas enteric or septicemic disease, being one of the most important causes of high mortalities in dairy calves. (Lofstedt et al., 1999). Some strains develop traits can be harmful to a host animal.

According to virulence factors and the clinical symptoms of the host, pathogenic E.coli strains are classified into Enterotoxigenic E.coli (ETEC), attaching and effacing $E$. coli, enteropathogenic $E$. coli, Shiga toxinproducing E.coli (STEC), and necrotoxigenic E. coli (Deb Roy et al., 2001; Nataro

Corresponding author: Dr. GHADA MAHER

E-mail address: uree2001@mail.ru

Present address: Animal Health Research Institute, Assiut Branch, Egypt and Kaper, 1998). Enterotoxigenic E.coli can cause severe diarrhea in newborn calves by production of heat-stable enterotoxin (STa). The most common observed fimbriae on ETEC from diarrheic calves is K99 (F5) and F41; however, strains with F17 fimbriae have also been isolated (Nagy and Fekete., 1999). STEC strains are the main cause of colibacillosis in newborn calves. Although both healthy and diarrheic calves carry STEC in their intestine, natural outbreaks and experimental infections have recorded the association of STEC with diarrhea and dysentery in young calve (DeanNystrom et al., 1997; Sandhu and Gyles, 2002) by production of Shiga toxins. These toxins are subdivided into two groups, Shiga toxin 1 (Stx1) and Shiga toxin 2 (Stx2). Stx1 is a homologous group in which three variants (Stx1, Stx1c and Stx1d) have been describe (Bürk et al., 2003; Zhang et al., 2002). Stx2 is more heterogeneous and consist of several subtypes (Stx2, Stx2c, Stx2d, Stx2e, Stx2f, Stx2g and activatable Stx2d) (Leung et al., 2003; Nataro and Kaper, 1998; Piérard et al., 1998; Schmidt et al., 2000). In addition to toxin production, STEC strainshave other virulence factors such as intimin 
(encoded by the eae gene) (Nataro and Kaper., 1998) the plasmid-encoded enterohemolysin (encoded by the ehxA gene) (Schmidt et al., 1995) and the STEC autoagglutinating adhesion (Saa) (Paton et al., 2001).

Serogrouping of E.coli was carried out to give an idea about the most predominant serogroups associated with diarrhea in calves (Blanco et al., 2004; Ugrinovich et al., 2007; Shahrani et al., 2014).

Congo Red Agar test was used to differentiate invasive and noninvasive E.coli in poultry, this test was used to detect enteroinvasive E.coli of bovine origin (Sharma et al., 2006). Antibody and complement have been found the main component that made the bactericidal effect of serum against grame negative bacteria, more over complement activity responsible for bactericidal activity of serum by generating chemostatic factors and directly killing susceptible gram negative bacteria (Taylor, 1983). The ability of E.coli to survive in serum and grow in spite of the bactericidal activity of complement has recognized as an important attribution which contributes to its pathogenicity and suggests the possibility of multiplication in Blood stream (John et al., 1989). Hemolytic activity could be used a phenotypic character or virulence factors of E.coli serotypes (Gad EL-Said et al., 2005).

So, the aim of this study is detection of E.coli from diarrheic calves which can be achieved by isolation, identification, serotyping and detection of virulence gene by PCR.

\section{MATERIALS AND METHODS}

\section{Sample Collection (Salvadori et al., 2003)}

A total hundred and twenty five fecal samples of diarrheic calves ( $\leq 3$ monthes) were collected from different localities of Assiut. The fecal samples were obtained after stimulation of the rectal mucosa then they were collected in sterile plastic tubes and submitted into laboratory on ice packs. Samples were processed within 24-48 hours. After reception.

\section{Isolation and Identification of E.coli: (Quinn et al.,} 2004)

1- Samples were cultured on nutrient brothand incubated for 24 hours at $37^{\circ} \mathrm{C}$.

2- Isolation: subculture of bacterial growth on MaCconkey agar (Diffco) $\rightarrow$ lactose fermenter. (pink colonies). Acolony was picked and cultivated on Eosin methylene blue media (Oxoid) $\rightarrow$ green metalic sheen.(Quinn et al., 2004).

3- Identification: Biochemical conformation of the strains was performed by conventional IMVC (Indol, Methyl red, Vogesproskauer and Citrate utilizations tests) urease test, motility triple sugar iron agar (TSI) inculation and according to (Quinn et al., 2004) .

\section{Serological identification of E.coli: (Kok et al., 1996)}

- The isolates were serologically identified according to (Kok et al., 1996) by using rapid diagnostic E.coli antisera sets (DENKA SEIKEN Co., Japan) for diagnosis of the Enteropathogenic types. They include 8 vials of polyvalent in addition to the 44 vials of monovalent antisera and $6 \mathrm{H}$-sera.

Identification of virulence factors: (Sayed, 2014)

A- Haemolytic activity (haemolysin) (Beutin et al., 1989): E. coli isolates were inculated onto blood agar containing $5 \%$ sheep blood for detection of enterohaemolysis after 6 hours of incubation at $37 \mathrm{C}^{\circ}$.

B- Congo red (CR) binding test (Panigrahy and Yushen, 1990):

Congo Red Dye binding test (CR test) has been used to differentiate between invasive and non-invasive $E$. coli (Berkhoff and Vinal, 1986; Penigarhy and Yushen, 1990). The medium used for CR dye binding was tryptose agar with $0.2 \%$ galactose and $0.03 \% \mathrm{CR}$ due to $E$ coli isolates were streaks on to $\mathrm{CR}$ agar plates and incubated at room temperature for additional 48 hours. The colonies were examined at 18, 24, 48 and 72 hours of incubation. The E.coli that produced red colonies between 18 and 72 hours of incubation were recorded as Congo red positive and ones that produced grayish- white colonies and remainded so throughout the incubation period were recorded as Congo red negative. (Penigrahy and Yushen, 1990).

C- serum inactivation assay (Timmis, 1979):

E.coli isolates were incubated at $0.1 \%$ (V/V) inoculums level into glucose phosphate broth containing bromothymol blue and $2 \%$ human serum and incubated at $37 \mathrm{C}^{\circ}$ for 24 hours. The serum resistance was observed by changes in colour from green to yellow.

D- Invasiveness test (sereny test) (Sereny, 1955):

E.coli isolates were grown overnight in nutrient broth. The growth in centrifuged at $5000 \mathrm{rpm}$ for $15 \mathrm{~min}$ at $4 \mathrm{C}^{\circ}$ and the bacterial pellet was collected. The concentration was adjusted with $0.9 \%$ normal saline solution to $5 \times 10^{5} \mathrm{ml}$. A volum of approximately $50 \mu \mathrm{l}$ suspension was incubated at the conjunctival sac of guinea pig. Reaction was observed for 96 hours and development of kerato conjunctivitis is recorded as a positive reaction

\section{Polymerase chain reaction $(\mathrm{PCR})$ :}

Materials used for PCR:

Reagents used for agrarose gel electrophoresis:

Agarose powder, Biotechnology grade (Bioshop ${ }^{\mathrm{R}}$, Candainc.lot No: OE16323).

It prepared in concentration $2 \%$ in $1 \times$ TAE buffer. 
Tris acetate EDTA (TAE) electrophoresis buffer $\left(50 \times\right.$ liquid concentration) (Bioshop ${ }^{R}$, Candainc. lot No: 9E11854).

The solution diluted to $1 \times$ by adding $1 \mathrm{ml}$ stock solution to $49 \mathrm{ml}$ double dist. Water to be used in the preparation of the gel or as a running buffer.

Ethedium bromide solution (stock solution) biotechnology grade (Bioshop ® CandaInc, Lot No: 0A14667):

The stock solution was diluted by $25 \mu 1 / 200 \mathrm{ml}$ double distilled water and stored covered at $4^{\circ} \mathrm{C}$. It was used for staining of PCR products that electrophoreses on agarose gel to be visualized by UV light.

Gel loading buffer (6×stock solution) (Fermentas, lot No: ooo56239).
The components were dissolved in sterile double distilled water and stored covered with aluminum foil at room temperature.

DNA ladder (molecular marker): 100 bp (Fermentas, lot No: 00052518). $5 \mathrm{X}$ Taq master (Fermentas):

Containing polymerase enzyme, Magnesium chloride $\left(\mathrm{Mg} \mathrm{Cl}_{2}\right)$, Deoxy nucleotide triphosphate $(\mathrm{dNTP})$ and PCR grade water.

Primer sequences of E. coli used for PCR identification system:

Application of PCR for identification of shiga toxins (stx1 \& stx2) genes of E.coli was performed essentially by using primers (Pharmacia Biotech) as shown in the following table:

\begin{tabular}{|c|c|c|c|}
\hline Primer & $\begin{array}{c}\text { Oligonucleotide sequence }\left(\mathbf{5}^{\prime} \rightarrow \mathbf{3}^{\prime}\right) \\
\text { http://www.ncbi.nlm.nih.gov/pmc/articles/PMC1 } \\
\underline{40333 / \mathrm{table} / \mathrm{t} 2 /-\mathrm{t} 2 \mathrm{fn} 1}\end{array}$ & Product size (bp) & References \\
\hline stx1 (F) & 5' ACACTGGATGATCTCAGTGG '3 & \multirow{2}{*}{614} & Dhanashree and \\
\hline Stx1 (R) & 5' CTGAATCCCCCTCCATTATG '3 & & Mallya (2008) \\
\hline Stx2 (F) & 5' CCATGACAACGGACAGCAGTT '3 & \multirow{2}{*}{779} & Dhanashree and \\
\hline Stx2 (R) & 5' CCTGTCAACTGAGCAGCACTTTG '3 & & Mallya (2008) \\
\hline
\end{tabular}

2. DNA Extraction using QIA amp kit (Shah et al., 2009):

After overnight culture on nutrient agar plates, one or two colonies were suspended in $20 \mathrm{ml}$ of sterile distilled water, and the suspension was then heated at $100^{\circ} \mathrm{C}$ for 20 minutes. Accurately, 50-200 $\mu$ l of the culture were placed in Eppendorf tube and the following steps were carried out:

2.1. Equal volume from the lysate $(50-200 \mu \mathrm{l})$ was added, addition of $20-50 \mu 1$ of proteinase $\mathrm{K}$, then incubation at $56{ }^{\circ} \mathrm{C}$ for $20-30 \mathrm{~min}$. After incubation, $200 \mu \mathrm{l}$ of $100 \%$ ethanol was added to the lysate.

2.2. The solution was added to the column and centrifuged at $8000 \mathrm{rpm}$ for $1 \mathrm{~min}$. then the filtrate was discarded.

2.3. The sediment was washed using AW1 buffer $(200 \mu \mathrm{l})$, the column was centrifuged at $8000 \mathrm{rpm} / 1$ min, and the filtrate was discarded.

2.4. Washing was applied by using the AW2 buffer $(200 \mu \mathrm{l})$, the column was centrifuged at $8000 \mathrm{rpm} / 1$ min. and the filtrate was discarded.

2.5. The column was placed in a new clean tube then, 25-50 $\mu \mathrm{l}$ from the Elution buffer was added, centrifuged at $8000 \mathrm{rpm} / 1 \mathrm{~min}$. Then the column was discarded. The filtrate was put in clean tube containing the pure genomic DNA. Nucleic acid was eluted with $100 \mu \mathrm{l}$ of elution buffer provided in the kit.

\section{Amplification reaction of E. coli (Fagan et al., 1999):}

The amplification was performed on a Thermal Cycler (Master cycler, Eppendorf, Hamburg, Germany). PCR assays were carried out in $1 \mathrm{ml}$ of nucleic acid template prepared by using reference EHEC isolates (approximately $30 \mathrm{ng}$ of DNA), 10 mMTris- $\mathrm{HCl}$ (pH 8.4), $10 \mathrm{mMKCl}, 3$ mM MgCl2; 2 $\mathrm{mM}$ concentrations of each primer, $0.2 \mathrm{mM}$ concentrations of each 29-deoxynucleoside 59triphosphate, and $4 \mathrm{U}$ of Ampli Taq DNA polymerase (Perkin-Elmer). Amplification conditions consisted of an initial $95^{\circ} \mathrm{C}$ denaturation step for $3 \mathrm{~min}$ followed by 35 cycles of $95^{\circ} \mathrm{C}$ for $20 \mathrm{sec}, 58^{\circ} \mathrm{C}$ for $40 \mathrm{~s}$, and $72^{\circ} \mathrm{C}$ for $90 \mathrm{sec}$. The final cycle was followed by $72^{\circ} \mathrm{C}$ incubation for $5 \mathrm{~min}$. The reference strains were E. coli O157:H7 Sakai (positive for stx1, stx2 and eaeA) and $E$. coli $\mathrm{K} 12 \mathrm{DH} 5 \alpha$ (a non pathogenic negative control strain) that does not posses any virulence gene. Amplified DNA fragments were analyzed by $2 \%$ of agarose gel electrophoresis (Applichem, Germany, GmbH) in $1 \mathrm{x}$ TBE buffer stained with ethidium bromide and captured as well as visualized on UV transilluminator. A $100 \mathrm{bp}$ plus DNA Ladder (Qiagen, Germany, GmbH) was used to determine the fragment size. 
Table 1: Component of PCR Master Mix.

\begin{tabular}{cc}
\hline Component & Volume / Reaction \\
\hline Emerald Amp GT PCR mastermix (2x premix) & $\mathbf{1 2 . 5} \boldsymbol{\mu l}$ \\
\hline PCR grade water & $\mathbf{2 . 5} \boldsymbol{\mu l}$ \\
\hline Forward primer $(20 \mathrm{pmol})$ & $\mathbf{1} \boldsymbol{\mu l}$ \\
\hline Reverse primer $(20 \mathrm{pmol})$ & $\mathbf{1} \boldsymbol{\mu l}$ \\
\hline Template DNA & $\mathbf{6} \boldsymbol{\mu l}$ \\
\hline Total & $\mathbf{2 5} \boldsymbol{\mu l}$ \\
\hline
\end{tabular}

Table 2: Cycling conditions of the different primers during PCR.

\begin{tabular}{cccccc}
\hline Target gene & $\begin{array}{c}\text { Primary } \\
\text { denaturation }\end{array}$ & $\begin{array}{c}\text { Secondary } \\
\text { denaturation }\end{array}$ & Annealing & Extension & $\begin{array}{c}\text { Final } \\
\text { extension }\end{array}$ \\
\hline \multirow{2}{*}{ stx1 } & $95^{\circ} \mathrm{C}$ & $95^{\circ} \mathrm{C}$ & $58^{\circ} \mathrm{C}$ & $72^{\circ} \mathrm{C}$ & \\
& $3 \mathrm{~min}$. & $20 \mathrm{sec}$. & $20 \mathrm{sec}$. & $1.5 \mathrm{~min}$. & $72^{\circ} \mathrm{C}$ \\
\multirow{2}{*}{$\mathbf{s t x} 2$} & $95^{\circ} \mathrm{C}$ & $95^{\circ} \mathrm{C}$ & $58^{\circ} \mathrm{C}$ & $72^{\circ} \mathrm{C}$ & $5 \mathrm{~min}$. \\
\hline
\end{tabular}

\section{RESULTS}

Typical E.coli colonies were isolated from 58 fecal samples (46.4\%) out of 125 fecal samples followed by Enterobacteraerogenes were foundin 14 fecal samples (11.2\%). While Proteuemirabili were isolated from 10 fecal samples (8\%), Klebsiella pneumonia were found in 8 fecal samples (6.4\%), Hafnia species were recorded in 6 fecal samples (4.8\%), Citrobacterfreundii were isolated from 4 fecal samples (3.2\%) and 25 fecal samples had untyped bacteria as shown in table (3)

Table 3: Different types of bacteria isolated from fecal samples of calves suffer from diarrhea.

\begin{tabular}{ccc}
\hline Types of isolates & No of isolates & Percentage of isolates \\
\hline E.coli & 58 & $46.4 \%$ \\
\hline Enterobacteraerogenes & 14 & $11.2 \%$ \\
\hline Proteuemirabili & 10 & $8 \%$ \\
\hline Klebsiella pneumonia & 8 & $6.4 \%$ \\
\hline Hafnia species & 6 & $4.8 \%$ \\
\hline Citrobacterfreundii & 4 & $3.2 \%$ \\
\hline Untyped & 25 & $20 \%$ \\
\hline Total & 125 & $100 \%$ \\
\hline
\end{tabular}

The isolates of 58 E.coli were serologically identified by using rapid diagnostic E.coli antisera sets .It was recorded that O26:H11 was the most serotype found in E.coli isolates (17.24\%) followed by O111:H2 (13.7\%). While O128:H2, O91:H21,O121:H7,O55:H7 had the same percent (10.3\%), but O146:H21, O124 were recorded (6.9\%) finally, O113:H4.O103:H2,O15 and O8 were found with percent (3.4\%). As in table (4).

Table 4: Different serotypes of E.coli isolated from fecal samples of calves suffer from diarrhea.

\begin{tabular}{ccc}
\hline Serogroups & No. & $\%$ \\
\hline O26:H11 & 10 & $17.24 \%$ \\
\hline O111:H2 & 8 & $13.7 \%$ \\
\hline O128:H2 & 6 & $10.3 \%$ \\
\hline O91:H21 & 6 & 10.3 \\
\hline O121:H7 & 6 & 10.3 \\
\hline O55:H7 & 6 & 10.3 \\
\hline O146:H21 & 4 & $6.9 \%$ \\
\hline O124 & 4 & $6.9 \%$ \\
\hline O113:H4 & 2 & $3.4 \%$ \\
\hline O103:H2 & 2 & $3.4 \%$ \\
\hline O15 & 2 & $3.4 \%$ \\
\hline O8 & 2 & $3.4 \%$ \\
\hline Total & 58 & $100 \%$ \\
\hline
\end{tabular}


In Congo red binding test: We found that $80 \%$ of $\mathrm{O} 26: \mathrm{H} 11$ were positive for Congo red test followed by $75 \%$ of $\mathrm{O} 111: \mathrm{H} 2$, but $66.67 \%$ of each $\mathrm{O} 128: \mathrm{H} 2$, O91:H21 and O55:H7 only gave positive reaction. All of $\mathrm{O} 121: \mathrm{H} 7, \mathrm{O} 113: \mathrm{H} 4, \mathrm{O} 1.3: \mathrm{H} 2, \mathrm{O} 15$ and $\mathrm{O} 8$ were positive to Congo red test. Only O124 serotype did not respond to Congo red test. As in table (5)

In serum resistant test: We found that the results of serum resistant test had the same results of Congo red binding test. As in table (5)

In invasiveness test: In this study $20 \%$ of $\mathrm{O} 26: \mathrm{H} 11$ made conjunctivitis in guinea pig, $25 \%$ of $\mathrm{O} 111: \mathrm{H} 2$ gave positive reaction, $16.67 \%$ of $\mathrm{O} 128: \mathrm{H} 2$ had irritation in conjunctiva of guinea pig, while $33.3 \%$ of each $091: \mathrm{H} 21$ and $\mathrm{O} 121: \mathrm{H} 7$ were positive to Sereny test and 50\% of each $\mathrm{O} 113: \mathrm{H} 4$ and $\mathrm{O} 103: \mathrm{H} 2$ gave positive results of invasiveness test but $055: \mathrm{H} 7$, O146:H21, O124, O15 and $\mathrm{O} 8$ gave no reaction in this test. As in table (5)

Haemolytic activity: In this test only $10 \%$ of O26:H11 had a haemolytic activity on blood agar, $37.5 \%$ of $\mathrm{O} 111: \mathrm{H} 2$ gave positive reaction, while $33.3 \%$ of each $\mathrm{O} 128: \mathrm{H} 2$ and $\mathrm{O} 91: \mathrm{H} 21$ were recorded as positive results, $16.67 \%$ of each $0121: \mathrm{H} 7$ and O55:H7 made a haemolysis on blood agar and 50\% of each O113:H4, O103:H2, O15 and $\mathrm{O} 8$ gave positive results. Finally O146:H21 and O124 had no effect on blood agar. As in table (5)

Table 5: Relationship between different serogroups and phenotypic virulence factors of E.coli isolated from fecal samples of calves suffer from diarrhea.

\begin{tabular}{|c|c|c|c|c|c|}
\hline \multirow{2}{*}{ Serogroups } & \multirow{2}{*}{ No. } & $\begin{array}{l}\text { Congo Red } \\
\text { binding }\end{array}$ & $\begin{array}{c}\text { Serum } \\
\text { resistance }\end{array}$ & $\begin{array}{c}\text { Invasiveness } \\
\text { activity }\end{array}$ & Haemolytic activity \\
\hline & & $\begin{array}{c}\text { No. of +ve } \\
(\%)\end{array}$ & $\begin{array}{c}\text { No. of }+\mathrm{ve} \\
(\%)\end{array}$ & $\begin{array}{c}\text { No. of }+ \text { ve } \\
(\%)\end{array}$ & $\begin{array}{c}\text { No. of +ve } \\
(\%)\end{array}$ \\
\hline O26:H11 & 10 & $8(80 \%)$ & $8(80 \%)$ & $2(20 \%)$ & $1(10 \%)$ \\
\hline $\mathrm{O} 111: \mathrm{H} 2$ & 8 & $6(75 \%)$ & $6(75 \%)$ & $2(25 \%)$ & $3(37.5 \%)$ \\
\hline O128:H2 & 6 & $4(66.67 \%)$ & $4(66.67 \%)$ & $1(16.67 \%)$ & $2(33.3 \%)$ \\
\hline O91:H21 & 6 & $4(66.67 \%)$ & $4(66.67 \%)$ & $2(33.3 \%)$ & $2(33.3 \%)$ \\
\hline O121:H7 & 6 & $6(100 \%)$ & $6(100 \%)$ & $2(33.3 \%)$ & $1(16.67 \%)$ \\
\hline $\mathrm{O} 55: \mathrm{H} 7$ & 6 & $4(66.67 \%)$ & $4(66.67 \%)$ & 0 & $1(16.67 \%)$ \\
\hline O146:H21 & 4 & $2(50 \%)$ & $2(50 \%)$ & 0 & 0 \\
\hline $\mathrm{O} 124$ & 4 & 0 & 0 & 0 & 0 \\
\hline O113:H4 & 2 & $2(100 \%)$ & $2(100 \%)$ & $1(50 \%)$ & $1(50 \%)$ \\
\hline O103:H2 & 2 & $2(100 \%)$ & $2(100 \%)$ & $1(50 \%)$ & $1(50 \%)$ \\
\hline O15 & 2 & $2(100 \%)$ & $2(100 \%)$ & 0 & $1(50 \%)$ \\
\hline O8 & 2 & $2(100 \%)$ & $2(100 \%)$ & 0 & $1(50 \%)$ \\
\hline Total & 58 & $42(72.4 \%)$ & $42(72.4 \%)$ & $11(18.96 \%)$ & $14(24.13 \%)$ \\
\hline
\end{tabular}

Ten different serotypes of E.coli isolates were taken for multiplex PCR using shiga toxin 1(stx1) (614 bp) and shiga toxin 2(stx2) (779 bp) Genes for characterization of shiga toxin E.coli (STEC). The results were recorded as in table (6)

Table 6: Stx1 and Stx2 genes profile of ten serotypes E.coli strains isolated from calves suffer from diarrhea.

\begin{tabular}{ccc}
\hline Virulence genes. & Positive serogroups & Number of +veserogroups \\
\hline Stx1 & $\mathrm{O} 8, \mathrm{O} 113: \mathrm{H} 4, \mathrm{O} 128: \mathrm{H} 2$ & $3(30 \%)$ \\
\hline $\mathrm{Stx} 2$ & $\mathrm{O} 15, \mathrm{O} 146: \mathrm{H} 21$ & $2(20 \%)$ \\
\hline Stx1 and stx2 & $\mathrm{O} 26: \mathrm{H} 11, \mathrm{O} 91: \mathrm{H} 21, \mathrm{O} 103, \mathrm{O} 111: \mathrm{H} 2$ & $4(40 \%)$ \\
\hline Negative stx1 stx2 & $\mathrm{O} 124$ & $1(10 \%)$ \\
\hline
\end{tabular}




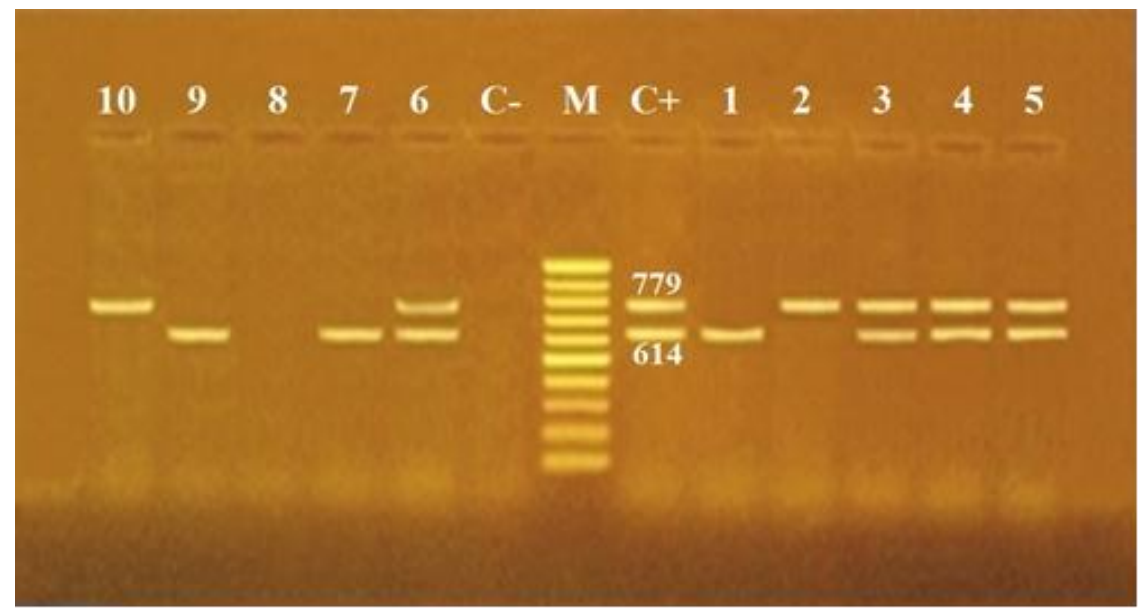

Figure (1): Agarose gel electrophoresis of multiplex PCR using shiga toxin 1(stx1) (614 bp) and shiga toxin 2(stx2) (779 bp) Genes for characterization of Enterotoxigenic E.coli.

Lane M: 100 bp ladder as molecular size DNA marker. Lane C+: Control positive E. coli for stx1, stx2. Lane C-: Control negative. Lanes $1(\mathrm{O} 8), 7$ (O113) \& 9 (O128): Positive E. coli strains for stx1 gene. Lanes $2(\mathrm{O} 15)$ \& 10 (O146): Positive E. coli strains for stx2 gene. Lanes 3 (O26), 4 (O91), 5 (O103) \& 6 (O111): Positive E. coli strains for stx1 and stx2 genes.

\section{DISCUSSION}

Diarrhoea due to the Enterotoxigenic E.coli (ETEC) is one of the most frequent bacterial diseases in neonatal calves and the predominant pathogen cultured from calves with septicaemia. Detailed studies of the virulence factors produced by E.coli strains in farm animals are needed. In this study 125 fecal samples of diarrhetic calves were used, coliforms were detected in one hundred fecal samples with the incidence of $80 \%$ (table 3 ). The incidence of E.coli is $(46.4 \%)$ followed by Enterobacteraerogenes (11.2\%), Proteuemirabili (8\%), Klebsiella pneumonia (6.4\%) Hafnia species (4.8\%), Citrobacterfreundii $(3.2 \%)$.

Serogrouping of E.coli was carried out to give an idea about the most important and predominant serogroupes found in diarrhetic calves. In thisstudy the obtained results showed that isolated E.coli belonged to 12 different serotypes O26:H11(10)O111: H2(8), O128:H2(6), O91:H21(6), O121:H7(6), O55:H7(6), O146:H21(4), O124(4), O113:H4(2), O103:H2(2), O15(2), O8(2). This results agree with (Blanco et al., 2004) who found different serotypes of shiga toxin E.coli including (O113,O26,O91,08); Shahrani et al. (2014) recorded different serotypes includind (O128,O113,O26,O121)

In table (5): These findings suggest that CR dye binding could be used as a phenotypic marker to distinguish between invasive and non-invasive isolates. In this study we found 42 strains $(72.4 \%)$ positive Congo red binding test. Such findings agree with Berkhoff and Vinal (1986) who found that about half of the $E$. coli was CR positive, which were obtained from environmental and cloacal origin. Likewise, Panigarhy and Yushen (1990) also found
13/ $21(61.9 \%)$ E.coliwere CR positive. Mousaet al. (2010) also found $90.9 \%$ of $E$.coli isolated from diarrheic sheep and $90 \%$ isolated from goat were positive to Congo red test; Sayed (2014) also found $72.2 \%$ E.coli positive Congo red.

It is assumed that serum resistance is an important virulence property of E.coli strains. The obtained results in this study showed that $42(72.4 \%)$ strains of E.coli positive to serum resistance as in table 5. Da Rocha et al. (2002) found $88.9 \%$ of E.coli positive to serum resistance; Sayed, (2014) found $83.3 \%$ of E.coli positive to serum resistance.

The term invasive E.coli referred to those strains of E.coli which able to induce keratoconjunctivitis in eyes of Guinea pig (Sereny test, 1955). The obtained results in this study showed that 11 isolates of E.coli $(18.96 \%)$ made positive reactions of Sereny test (keratoconjunctivities) in Guinea pigs as in table 5. Sharma et al. (2006) found the incidence of positive results were (58.69\%) Amira et al. (2013) found the positive results were $(40.5 \%)$; Sayed (2014) found the positive results were $(33.3 \%)$.

Some of E.coli strains have hemolytic action, in our study $14(24.13 \%)$ E.coli isolates had hemolytic activity table 5. Salvadori et al. (2003) found (9.8\%) of E.coli serotyped positive to hemolysis on blood agar. While Gad El-Said (2005) recorded that $(81.25 \%)$ of E.coli isolates show hemolytic activity.

PCR for detection of virulence factor producing by STEC in calves is very important finding to demonstrate predominate of $E$. coli serotype that mainly effect the calves and causes severe diarrhea. PCR analysis of ten different serotypes of E.coli strains represented the presence of stx1 and stx2 
genes in ten E.coli serogroupes (O26:H11, O91:H21, O103:H2， O111:H2， O15:H21， O146:H21， O8, O113:H4, O128:H2, O124). Using Shiga toxin1 (stx1) (614 bp) and Shiga toxin 2(stx2) (779 bp) Genes for characterization of shiga toxin E.coli. The serotypes which positive to stx1gene only were three (O8,O113:H4, O128:H2) (30\%), two serotypes were positive to stx2 only (O15:H21, O146:H21) (20\%), four serotypes were positive to both stx1 and stx2 (O26:H11, O91:H21, O103:H2,O111:H2) (40\%) and O124 was negative for both stx1 and stx2 (10\%). Salvadori et al. (2003) recorded stx1 were 20(9.8\%) and stx2 were $13(6.34 \%)$ out of 205 E.coli isolates. Nguyen et al. (2010) found stx1 were 46(13.3\%), stx2 were $73(21.15 \%)$ and both stx1 and stx2 were $58(16.81 \%)$. But our study disagree with Luna (2008) who found that stx 1 gene positive in $12.2 \%$ of total samples, stx 2 positive in $7.8 \%$ but both stx 1 and stx 2 were found in $15.2 \%$.

\section{CONCLUSION}

The high number of STEC strains isolated from diarrheic calves implies that these animals are an important reservoir of STEC strains that are potentially pathogenic toward farm animals.

\section{ACKNOWLEDGEMENT}

Many thanks to professor Dr. Sayed Mohamed, Head of Microbiology department. Animal Health Research Institute, Assuit Branch, Egypt. For his technical support.

\section{REFERENCE}

Amira, ElSayed. Lamey; Ammar, A.M.; Zaki, E.R.; Norhan, K.; Badea, S.M. and Refai, M.K. (2013): Virulence factors of Escherichia coli isolated from recurrent cases of clinical and subclinical mastitis in buffaloes. International J. of Microbiological Research, 4(1), 86-94.

Berkhoff, H.A. and Vinal, A.C. (1986): Congo red medium to distinguish between invasive and non invasive Escherichia coli pathogenic for poultry. Avian Dis. 30, 117-121.

Beutin, L.; Montenegro, M.A.; Orskov, I.; Oswald, E.; Orskov, F.; Prada, J.; Zimmerman, S. and Stephan, R. (1989): Close association of verotoxin (Shiga like toxin) production with enterohaemolysin production in strains of $E$. coli J. Clin Microbiol. 27(11): 2559-2564.

Blanco, J.E.; Blanco, M.; Alonso, M.P.; Mora, A.; Dahbi, G.; Coira, M.A. and Blanco, J. (2004): Serotypes, virulence genes, and intimin types of Shiga toxin (verotoxin)-producing Escherichia coli isolates from human patients: prevalence in Lugo, Spain, from 1992 through 1999. J. Clin Microbiol, 42, 311-319.
Bürk, C.; Dietrich, R.; Açar, G.; Moravek, M.; Bülte, M. and Märtlbauer, E. (2003): Identification and characterization of a new variant of Shiga toxin 1 in Escherichia coli ONT:H19 of bovine origin. J. Clin Microbiol. 41, 2106-2112.

DaRocha, A.C.; DaSilva, A.B.; DeBrito, A.B.; Moraes, H.L.; Pontes, A.P.; Ce, M.C.; DoNascimento, V.P. and Salie, C.T. (2002): Virulence factors of avian pathogenic E.coli isolated from boilers from the south of Brazil. Avian Dis., 46(3):749-753.

Dean-Nystrom, E.A.; Bosworth, B.T.; Cray, W.C. and Jr, Moon, H.W. (1997): Pathogenicity of Escherichia coli $\mathrm{O} 157: \mathrm{H} 7$ in the intestines of neonatal calves. Infect Immun. 65, 1842-1848.

DebRoy, C. and Maddox, C.W. (2001): Identification of virulence attributes of gastrointestinal Escherichia coli isolates of veterinary significance. Anim Health Res Rev. 2, 129140.

Dhanashree, B. and Mallya, S. (2008): Detection of shiga-toxigenic Escherichia coli (STEC) in diarrhoeagenic stool and meat samples in Mangalore, Indian J. Med. Res., 128: 271-277.

Fagan, P.; Hornitzky, M.; Bettelheim, K. and Djordjevic, S. (1999): Detection of shiga-like toxin (stx1 and stx2), Intimin (eaeA), and Enterohemorrhagic Escherichia coli (EHEC) Hemolysin (EHEC hlyA) genes in animal feces by multiplex PCR. Appl. Environ. Microbiol.65 (2): 868-872.

Fecteau, G.; Van Metre, D.C.; Pare, J.; Smith, B.P.; Higgins, R.; Holmberg, C.A.; Jang, S. and Guterbock, W. (1997): Bacteriological culture of blood from critically ill neonatal calves. Canadian Veterinary Journal, 38, 95-100.

Gad El Said, W.A.; El-Jakee, J.K.; Xandel, M. and Mona, A. Elshabrawy, (2005): Presence of E.coli O157:H7 in Raw milk and meat samples. J. Egypt Vet. Med. Ass., 65(3): 341-350.

John, M.; Jacques, M. and Lariviere, S. (1989): Pathogenicity of E.coli O115:KV165 strains isolated from pigs with diarrohea. Am. J. Res., 50(1): 1029-1036.

Kok, T.; Worswich, D. and Gowans, E. (1996): Some serological techniques fir microbial and viral infections. In practical Medical Microbiology (collee, J.; Fraser, A.; Marmion, B. and Simmons, A., eds.), Edinburgh, Churchill.

Leung, P.H.M.; Peiris, JSM.; N.g., WWS.; RobinsBrowne, R.M.; Bettelheim, K.A. and Yam W.C. (2003): A newly discovered verotoxin variant, VT2g, produced by bovine verocytotoxigenic Escherichia coli. Appl Environ Microbiol.69, 7549-7553.

Lofstedt, J.; Dohoo, I.R. and Duizer, G. (1999): Model to predict septicaemia in diarrheic calves. Journal of Veterinary Internal Medicine, 13, 81-88. 
Luna, Carlos, V.H. (2008): Infectious agents associated with diarrhoea of calves and characterization of virulence genes in Escherichia coli isolated from diarrheic and healthy neonatal calves in Austerlia.

Mousa, M.S.; Akeila, M.A.; Khalil, S.A. and Abdellrazeq, G.S. (2010): Virulence factors of Escherichia coli isolated from diarrheic sheep and goats. Alex. J. Vet. science 2010 vol.30 No.1 (137-147).

Nagy, B. and Fekete, P.Z. (1999): Enterotoxigenic Escherichia coli (ETEC) in farm animals Vet. Res. 30, 259-284.

Nataro, J.P. and Kaper, J.B. (1998): Diarrhoeagenic Escherichia coli. Clin Microbiol Rev. 11, 142201.

Nguyen, T.D.; Vo, TT. and Vu-Khac, H. (2011): Virulence factors in Escherichia coli isolated from calves with diarrhea in Vietnam. $\mathrm{J}$ Vet Sci, 12(2): 159-164.

Panigarhy, B. and Yushen, L. (1990): Differentiation of pathogenic and non-pathogenic Escherichia coli isolated from poultry. Avian. Dis. 34, 941943.

Paton, A.W.; Srimanote, P.; Woodrow, M.C. and Paton, J.C. (2001): Characterization of Saa, a novel autoagglutinating adhesion produced by locus of enterocyte effacement-negative Shiga-toxigenic Escherichia coli strains that are virulent humans. Infect Immun.69, 69997009.

Piérard, D.; Muyldermans, G.; Moriau, L.; Stevens, D. and Lauwers, S. (1998): Identification of new verocytotoxin type 2 variant B-subunit genes in human and animal Escherichia coli isolates. J. Clin Microbiol. 36, 3317-3322.

Quinn, P.J.; Carter, M.E.; Markey, B. and Carter, G.R. (2004): Clinical veterinary microbiology. 6th ed., Mosby, Edinbugh, London, New York, Philadelphia, St. Louis, Sydney, Toronto.

Salvadori, M.R.; Valadares, G.F.; Silva Leite, D. and Yano, T. (2003): Virulence factors of Escherichia coli isolated from calves with diarrhea in Brazil. Braz. J. Microbiol. 34: 230235.

Sandhu, KS. and Gyles, CL.(2002): Pathogenic Shiga toxin-producing Escherichia coli in the intestine of calves. Can J Vet Res .66, 65-72
Sayed, S.M. (2014): Acontribution on coliforms causing mastitis in cow a with reference to serotypes and virulence factors of E.coli isolates. Ass. univ. Vol., 17 No 1.

Schmidt, H.; Beutin, L. and Karch, H. (1995): Molecular Analysis of the Plasmid-Encoded Hemolysin of Escherichia coli O157:H7 Strain EDL 933. Vol. 63, No. 3. p. 1055-1061.

Schmidt, H.; Scheef, J.; Morabito, S.; Caprioli, A.; Wieler, L.H. and Karch, H. (2000): A new Shiga toxin 2 variant (Stx2f) from Escherichia coli isolated from pigeons. Appl Environ Microbiol.66, 1205-1208.

Sereny, B. (1955): Experimental shigella keratoconjuctivitis. Acta Microbiol. Asad. Sci. Hung., 2:293-296.

Shah, D.; Shringi, S.; Besser, T. and Call, D. (2009): Molecular detection of foodborne pathogens, Boca Raton: CRCPress, In Liu, D. (Ed). Taylor \& Francis group, Florida, USA, Pp. 369-389.

Shahrani Masoud; Farhad, Safarpoor, Dehkordi and Hassan, Momtaz (2014): Biological Research, 47: 28Arhiv, 76(4), 363-366.

Sharma, K.K.; Soni, S.S. and Meharchandani, S. (2006): Congo red dye test as an indicator test for detection of invasive bovine Escherichia coli -short communication. Veterinarski

Taylor, P.W. (1983): Bactericidal and Bacteriolytic of serum against Gram negative bacteria. Microbial. Rev., 47:46-83.

Timmis, K.N. (1979): Plasmid gene that specifies resistance to the bacterial activity of serum.In Plasmids of medical, environmental and commercial importance. Eddited by K.N. Timmis and Biomedical press, New York,145153.

Ugrinovich, J.; Blanco, M.; Blanco, J.E.; Blanco, L.; Leomil, G.; Dahbi, A.; Mora, D.L.; Onuma, W.D.; Silveira, A.F. and Pestana de Castro (2007): International Journal of Food Microbiology 115, 297-306.

Zhang, W.; Bielaszewska, M.; Kuczius, T. and Karch, $H$. (2002): Identification, characterization, and distribution of a Shiga toxin1 gene variant (stx1c) in Escherichia coli strains isolated from humans. J.Clin Microbiol.44, 1441-1446. 


\section{دراسه عن عوامل الضراوة للأشيرشيا كولاي المعزولة من العجول التي تعاني من الإسهال \\ غاده ماهر عبل الحكيم محد ، محد وائل عبد العظيم ، سراج اللين سلطان ، أحد مصطفى سبي}

Email: uree2001@mail.ru Assiut University web-site: www.aun.edu.eg

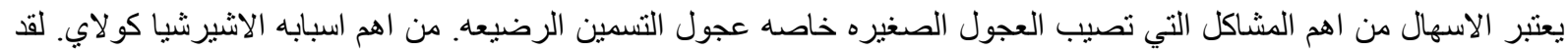

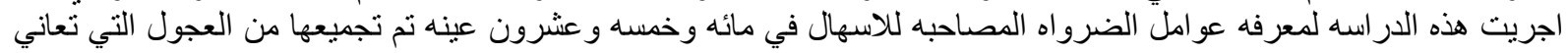

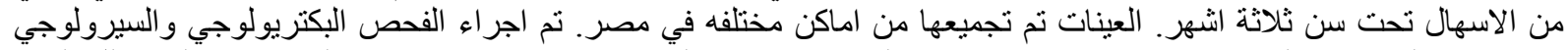

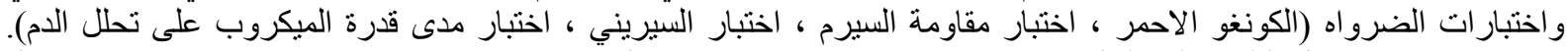

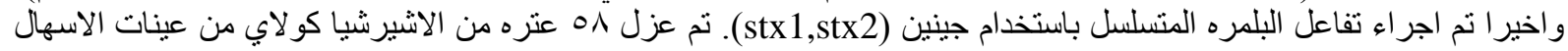

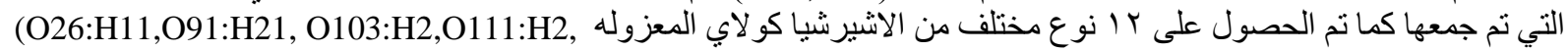

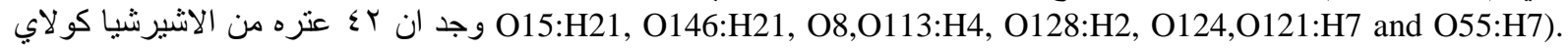

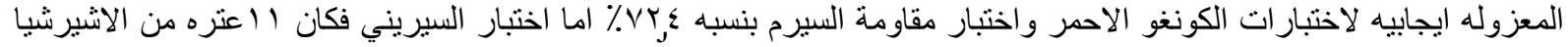

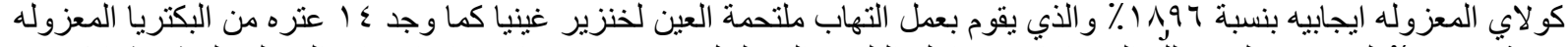

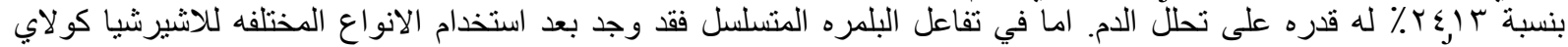

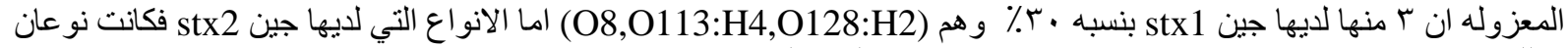

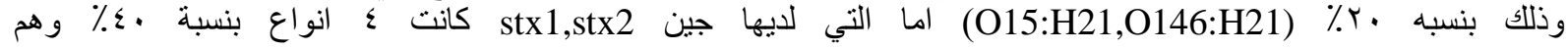
.(O26:H11,O91:H21,O103:H2,O111:H2) هذه النتائج تبين مدى اهميه العجول الصغيره التي تعاني من الاسهال كحامل الميكروب (STEC) ونقله الي الحيو انات الاخرى . 